\title{
The occurrence of Orthoreovirus, Rotavirus and chicken anemia virus in chickens of the poultry industry in Minas Gerais, Brazil
}

[Ocorrência de Orthoreovirus, Rotavirus e vírus da anemia das galinhas em frangos de corte da indústria avícola de Minas Gerais]

\author{
R.L. Rios ${ }^{1}$, S.Y.Marin ${ }^{1}$, A.M. Gomes ${ }^{1}$, J.S. Resende ${ }^{2}$, M.R.Q. Bonfim ${ }^{3}$, A.D. Gomes ${ }^{3}$, \\ F.M.S. Resende ${ }^{1}$, R.S. Horta ${ }^{4}$, M. Resende ${ }^{2}$, N.R.S. Martins ${ }^{2}$
}

\footnotetext{
${ }^{1}$ Aluno de pós-graduação - Escola de Veterinária - Universidade Federal de Minas Gerais - Belo Horizonte, MG ${ }^{2}$ Escola de Veterinária - Universidade Federal de Minas Gerais - Belo Horizonte, MG

${ }^{3}$ Aluno de pós-graduação - Instituto de Ciências Biológicas - Universidade Federal de Minas Gerais, UFMG

${ }^{4}$ Aluno de graduação - Escola de Veterinária - Universidade Federal de Minas Gerais - Belo Horizonte, MG
}

\begin{abstract}
Fifty-four fecal samples taken from broiler chickens from 1 to 45 days of age, and of pullets from 10 to 13 weeks of age, original from eight different poultry regions in the state of Minas Gerais, Brazil, were collected from March 2008 to January 2010 for avian Orthoreovirus (ARV) and avian Rotavirus (AvRV) analyses. For the assay of ARV, RNA was immediately extracted (Trizol ${ }^{\circledR}$ ) and transcribed into cDNA for assaying in a nested-PCR with ARV-specific primers. For AvRV, polyacrylamide gel electrophoresis (PAGE) was performed with RNA extracts obtained by phenol-chloroform extraction. CAV was additionally investigated through a nested-PCR of thymus and spleen. Results found 5.55\% positive for ARV and $9.25 \%$ for AvRV. Also, CAV and ARV genomes were detected in co-infection, in a highly prostrated and claudicating chicken flock. No ARV or AvRV infections were detected in pullets. Material of a clinically affected flock was inoculated into SPF embryos, resulting in embryonic hemorrhage, whitish foci in the chorio-allantoic membrane and death. Sequencing of ARV amplicons and isolate cDNA grouped local strains with the ARV S1133 strain, historically used in live vaccines, suggesting the continued circulation of this vaccine virus strain in intensive poultry regions. Detection rates for ARV and $\mathrm{AvRV}$, as well as the presence of CAV, were additionally indicative of failing biosecurity strategies for the intensive poultry regions examined.
\end{abstract}

Keywords: Broiler, layer, chicken anemia virus, CAV, avian reovirus, ARV, avian rotavirus, AvRV, nested-PCR, PAGE.

\section{RESUMO}

Avaliou-se a ocorrência de Orthoreovirus $(A R V)$ e Rotavirus (AvRV) aviários na avicultura industrial de Minas Gerais. Foram colhidas cinquenta e quatro amostras de fezes de frangos de corte entre um e 45 dias e de frangas de postura de 10 a 13 semanas de idade. Para análise de ARV, o RNA foi imediatamente extraído (Trizol), transcrito em cDNA e avaliado em uma PCR com oligonucleotídeos iniciadores específicos para ARV. Para a investigação de AvRV, os extratos de RNA foram obtidos por fenol-clorofórmio e submetidos à eletroforese em gel de poliacrilamida. Todas as amostras foram também avaliadas para o DNA do vírus da anemia das galinhas (CAV) em uma nested-PCR específica. Em frangos de corte, a positividade encontrada para ARV foi de 5,55\% e para AvRV de 9,25\%. CAV foi detectado em coinfecção em um plantel com refugagem, claudicação e prostração. Nenhuma amostra de poedeiras foi positiva para ARV ou AvRV. Material de plantel com sinais clínicos foi purificado e inoculado em ovos SPF embrionados, sendo obtidas lesões hemorrágicas e focos brancos na membrana cório-alantóide. O sequenciamento dos produtos de PCR e de embrião agrupou os isolados de ARV com a estirpe $S 1133$, historicamente usada como vacina viva. Os resultados sugerem a continuada circulação

Recebido em 9 de março de 2011

Aceito em 6 de setembro de 2012

E-mail: nrsmart@gmail.com 
da infecção por estirpes assemelhadas a ARV S1133 nas regiões de avicultura industrial. Os índices de detecção de ARV, AvRV e CAV indicam que a intensificação nas regiões produtoras tem resultado em falhas de biosseguridade.

Palavras-chave: Frango de corte, poedeira, reovirus, rotavirus, vírus da anemia das galinhas, nested$P C R, P A G E$.

\section{INTRODUCTION}

Orthoreovirus and Rotavirus are genera of Reoviridae, which in chickens and other species are usually involved in enteritis, stunted and poorer growth, reduced productive performance and higher mortality rates (McFerran et al., 1983; Andral et al., 1985; Gouch et al., 1988; Decaesstecker et al., 1988; Martins et al., 2009). The denomination reovirus derives from an acronym of respiratory and enteric orphan (REO), due to early isolated viruses not being associated to a clinical condition, the recent suffix ortho added to designate the genus for early isolates. Viruses of Reoviridae contain double stranded RNA divided, for Orthoreovirus into 10 segments or for Rotavirus into 11 segments. Virions are characterized by particles of about $100 \mathrm{~nm}$ in diameter, with triple-layered icosahedral protein capsid, with 60 external capsid spikes, an external capsid which requires calcium for integrity and virions which contain RNA-dependent RNA polymerase. Avian orthoreoviruses are mostly fusogenic of cell cultures and the $\mathrm{S}$ gene sigma $(\sigma) \mathrm{C}$ protein (outer capsid) acts as cell-attachment protein, hemagglutinin and primary serotype determinant (Shiff et al., 2007). Multiple syndromes are described resulting from ARV infections. Older birds are more resistant and remain infected for long periods of time, acting as source for the more susceptible young. Infected breeders transmit ARV vertically, through the egg or horizontally, as for AvRV, via fecal-oral route (Jones et al., 1975). Infected hatchlings and young develop the gastro-intestinal signs which will result in poor growth and lower performance, and survivors may develop arthritis (Van der Heide et al., 1975). A novel Orthoreovirus was isolated from the necrotic liver of affected Anas platyrhynchos (Pekin ducks) flocks with up to $40 \%$ mortality (Chen $e t$ al., 2012). For AvRV, the horizontal challenge, due to the high titers available in feces, up to $10^{10}$ a $10^{12}$ viral particles per gram (Flewett and Woode, 1978) will result in similarly poor performance in chickens and turkeys mostly from 6 to 14 days of age (McNulty et al., 1980). The virus appears to be shed mainly from the intestine and for longer periods, suggesting fecaloral contamination as a principal mode of infection (Rosenberger, 2003). For the diagnosis of ARV, specific nested-polymerase chain reaction (PCR) protocols have been described for amplifying a region of the S1gene encoding the $\sigma \mathrm{C}$ protein (Liu et al., 1997) region best suited for demonstrating diversity ((Shiff et al., 2007). Nested PCR reactions reduce or eliminate nonspecificity and increase sensitivity for ARV detection (Liu et al., 1997).

PAGE (polyacrylamide gel electrophoresis) of AvRV will separate the 11 segments of the viral RNA according to the molecular sizes (McNulty et al., 1980). Previous studies were reported in Minas Gerais (Alfieri et al., 1988; Rios et al., 2010). This study was proposed for the evaluation of the occurrence of ARV and AvRV, as well as CAV, for defined flocks in poultry regions in Minas Gerais.

\section{MATERIALS AND METHODS}

The geographical locations of the sampling areas were distributed to evaluate some of the most important poultry areas (Table 1). Fifty-four flocks of broiler or layer chickens were sampled from March 2008 to January 2010. Flocks were selected at random and included normal and diarrheic/clinically ill. Fecal samples were evenly distributed per house $(\mathrm{n}=20)$, totaling 1,080 samples. Samples were pooled for each flock for analyses. Broilers were from 1 to 45 days of age and pullets were from 10 to 13 -week of age. Each sample was collected into a new autoclaved flip top tube $(1.5 \mathrm{~mL})$ and frozen at $70{ }^{\circ} \mathrm{C}$ until the preparation of pools. A dilution factor was established for feces during standardization, by serially diluting (base 10) the ARV vaccine mixed with SPF chicken feces. A $10^{-2}$ dilution was chosen for studying all field samples. 
The RNA extraction (Trizol@) was based on a protocol designed for infectious bursal disease virus (IBDV) (Gomes et al., 2005). The quantified RNA was immediately transcribed (300ng) into ARV cDNA using reverse transcriptase (M-MLV, PROMEGA, USA) according to the manufacturer, with primer 5' ATTGAATTCTCTGTTATCTCAACCTTG 3.' For the first ARV PCR reaction, the external primer oligonucleotides was S1C 5, ATTGAATTCTCTGTTATCTCAACCTTG ${ }^{\prime}$ ' and S1D 5' AAGGAATTCGTTGAGAACAGAAGTAGG 3', described for amplifying the S1 gene region encoding the $\sigma \mathrm{C}$ protein (Liu et al.,1997), in reactions with $50 \mu$ volumes. In each assay, the cDNA transcribed from RNA of Poulvac ${ }^{\circledR}$ Maternavac IBD-Reo Orthoreovirus strain (Fort Dodge) was used as positive control. In order to prepare the positive control, a sample of reconstituted vaccine $(10 \mu \mathrm{L})$ was mixed with the feces $(500 \mathrm{mg})$ of SPF chickens for extraction. As negative controls, reactions with all reagents and without cDNA were used. ARV nested-PCR reactions were performed using the amplicon of the first reaction as a template and the internal oligonucleotides S1E 5TCTGAATTCATCGCAGCGAAGAGAGGT CG-3' and S1F 5'-AGTGAATTCAGTAT CGCCGCGTGCGCAG-3' as primers (Liu et al., 1997). Electrophoresis in $1 \%$ agarose stained by ethidium bromide and visualized in ultraviolet transilumination was used for the visualization of the 738bp amplified amplicons of the first reaction and $342 \mathrm{bp}$ of the nested reaction.

One of the ARV PCR positive pooled fecal samples was suspended in equal parts sterile PBS and clarified at $2.000 \mathrm{xg} / 10 \mathrm{~min}$. The supernatant was collected and treated with penicillin $G$ $(1,000$ units $/ \mathrm{mL})$, streptomycin $(500 \mu \mathrm{g} / \mathrm{mL})$ and amphotericin B $(1 \mu \mathrm{g} / \mathrm{mL})$ for $30 \mathrm{~min}\left(25^{\circ} \mathrm{C}\right)$ and inoculated into the 10th day of incubation specific pathogen free (negative for Orthoreovirus) chicken eggs $(n=10)$ via the chorioallantoic membrane (CAM). Eggs were candled and death was recorded daily. Dead embryos up to 24 hours post inoculation were discarded and the others examined for lesions and tissues collected for PCR. Harvested CAM were macerated, treated with antibiotics and passed in eggs three times to demonstrate embryonic effects and PCR detection.
DNA extracts were used for nested-PCR reactions specific for chicken anemia virus (CAV), as described previously (Cardona et al., 2000; Barrios et al., 2009).

Amplified PCR products (PTC-100, MJ Research, Inc., USA) were sequenced by chain termination (dideoxynucleotide), as described previously (Sanger et al., 1997), in an automated capillar sequencer (ABI 377, Perkin Elmer, USA) and Big Dye Terminator Mix (Applied Biosystems, USA), according to the manufacturer. Each sample was sequenced in both directions, as many times as needed for highest certainty, the quality of sequences evaluated using Bioedit (Hall, 1999) and compared to data at the National Center for Biotechnology Information (NCBI http://www.ncbi.nlm.nih.gov/). Four independent PCR reactions (BigDye labeled) were performed, twice for the forward primer and twice for the reverse primer, for sequencing each product.

The alignment of cDNA and deducted amino acid sequences were processed using Clustal W version 1.6 (Molecular Evolutionary Genetics Analysis - MEGA 3.1/ www.megasoftware.net) version 3.1 for Windows. The alignments of gene coding for ARV protein $\sigma 1$ were used for preparing phylogenetic trees (MEGA 3.1 www.megasoftware.net).

For the diagnosis of AvRV, polyacrylamide gel electrophoresis (PAGE) of phenol-chloroformisoamyl alcohol $(25: 24: 1)$ extracted fecal RNA was stained with silver nitrate (Herring et al., 1982; Alfieri, 1989; Alfieri, 1992). Stored fecal samples $\left(-20^{\circ} \mathrm{C}\right)$ were thawed, separately homogenized with disposable plastic sticks and diluted (1:7) in a Rotavirus buffer (TERV) $(\mathrm{pH}$ 7.4 -Tris- $\mathrm{HCl} 50 \mathrm{mM} ; \mathrm{NaCl} 10 \mathrm{mM} ; \mathrm{CaCl} 2$ $13 \mathrm{mM} ; \beta$-mercaptoethanol $1.5 \mathrm{mM})$. Dilutions were mixed (vortex, GENIE BENDER, model $\mathrm{K}-550 \mathrm{G}$, USA) and clarified at 2,000 x g/15min (FANEM, model 240-N, Brazil). Supernatants were transferred to $1.5 \mathrm{~mL}$ flip-top microtubes for RNA extraction. Approximately 300 nanograms of total RNA were applied to the $3.75 \%$ acrylamide (acrylamide/bisacrylamide) stacking gel. Electrophoresis was run in $7 \%$ resolving gel in Tris-glycine (Tris $25 \mathrm{mM}$, glycine $0,2 \mathrm{M}$, $\mathrm{pH} 8,6)$, with constant voltage $(100 \mathrm{~V})$ during 4 hours. Gels were fixed in ethanol-acetic acid, stained with silver nitrate $(0,11 \mathrm{M})$, developed in 
$\mathrm{NaOH}$-formaldehyde and preserved in $20 \%$ ethanol $\left(4^{\circ} \mathrm{C}\right)$.

This study was approved by the Ethics Committee in Animal Experimentation, certificate 074/2007 of August 8th, 2007.

\section{RESULTS AND DISCUSSION}

ARV and AvRV were detected in the broiler industry in Minas Gerais (Table 1). Three out of 54 broiler flocks, at 8,12 and 31 days-old, the first and third clinically affected, were positive for amplicons compatible in molecular mass to the expected ARV product. Broilers were of the intensified regions of Divinópolis, Pará de Minas and São Sebastião do Oeste. Five out of 54 (9.25\%) flocks showed the typical 11-band RNA segments by PAGE, indicative of AvRV, present in the regions of Pará de Minas, São Sebastião do Oeste and Pitangui. Two out of 3 flocks (66\%) were positive for ARV and showed enteric signs and one positive flock was clinically normal. All AvRV positive flocks were clinically affected (diarrhea). Considering the overall clinically affected flocks $(n=7)$, the relative indexes for ARV (42\%) and AvRV (57\%) are indicative of major roles for these viruses. Failed or lack of biosecurity, intensification and proximity of flocks of broiler chickens, may have a role in the detected occurrence of ARV and AvRV, as samples were obtained from chickens of densely broiler populated areas, and susceptible floor raised flocks may facilitate fecal-oral infection (Rosenberger, 2003).

For ARV positive flocks, signs of uneven growth $(2 / 3)$ and lameness (1/3) were noted. ARV has been associated with stunting of young birds, chickens with less than 15 days of age (Ruff and Rosenberger, 1985), supporting the finding of positive 8-day old broilers. The slightly higher ARV occurrence (13.5\%) previously detected by PAGE in broilers with diarrhea in Paraná state (Tamehiro et al., 2003) may be due to biosecurity differences. No inference could be drawn toward the role of ARV or AvRV in the clinical aspects (diarrhea) of flocks. In agreement, two Dutch and one German ARV derived from malabsorption syndrome did not cause weight gain depression in the broilers, although lesions in the small intestine were present from day 1 to day 4 PI and were more severe in broilers than in the white leghorn chickens (Songserm et al., 2003). However, infection with Orthoreovirus strain ARV-CU98 $(10 \mathrm{pfu} / \mathrm{ml} / \mathrm{chick})$ in broilers resulted in depressed growth, increased mortality and reduced protein concentration in various tissues (Burgos et al., 2006).

A co-infection of ARV and CAV (chicken anemia virus) was detected in the 31-day-old flock, with CAV present in the thymus and spleen. A previous CAV study in the region has shown disseminated infection in broilers (data not shown). CAV mostly causes cellular immune depression in chickens, and may have a role in the clinical effects of prostration and anorexia, in addition to arthritis and diarrhea observed in the flock. Immune compromised flocks will present the most severe effects (McNeilly et al, 1995; Rosenberger, 2003). Field conditions will enable co-infections with a range of primary and opportunistic pathogens (Andral et al., 1985), and the co-infection ARV / CAV may enable sufficient immune depression for an evolutive advantage of ARV variants. However, this is the first study detecting ARV and CAV natural coinfection in Brazil.

ARV was previously reported in chickens with enteric problems in Brazil (Alfieri et al., 1988; Alfieri et al., 1989; Tamehiro et al., 2003; Villareal et al., 2006), and in several countries such as United States, Australia, Sweden, England and Germany (Apple et al., 1991; Lenz et al., 1998). ARV has also been described as affecting growth and causing mortality in broilers by infecting the digestive system, and also the heart and articulations, mainly the hock joint (Rosenberger, 2003).

The embryo isolated strain caused $70 \%$ mortality of embryos at 24,48 and $72 \mathrm{~h}$ post infection at the third passage and was successfully detected by PCR. Chorioallantoic membranes were swollen and with whitish foci and embryos presented with superficial, hepatic and renal hemorrhages, and hepatic enlargement. Negative control eggs did not show lesions and were negative for ARV by PCR.

The sequencing of ARV PCR products has enabled comparisons with the data available (GenBank, NCBI, USA). ARV sequences were grouped (77\%) with S1133-derived strains (Figure 1). The attenuated S1133 vaccine strains 
were used for a few decades for vaccinating breeding flocks in Brazil and the virus may have been maintained through cyclic infections among flocks in densely populated areas, and might have reversed in pathogenesis causing the localized arthritis lesions. However, a large degree of variation in the $\mathrm{N}$-terminal region of ARV $\sigma \mathrm{C}$ when USA and Australian isolates were compared and correlation among USA isolates was consistent with serotyping (Liu et al., 1997).

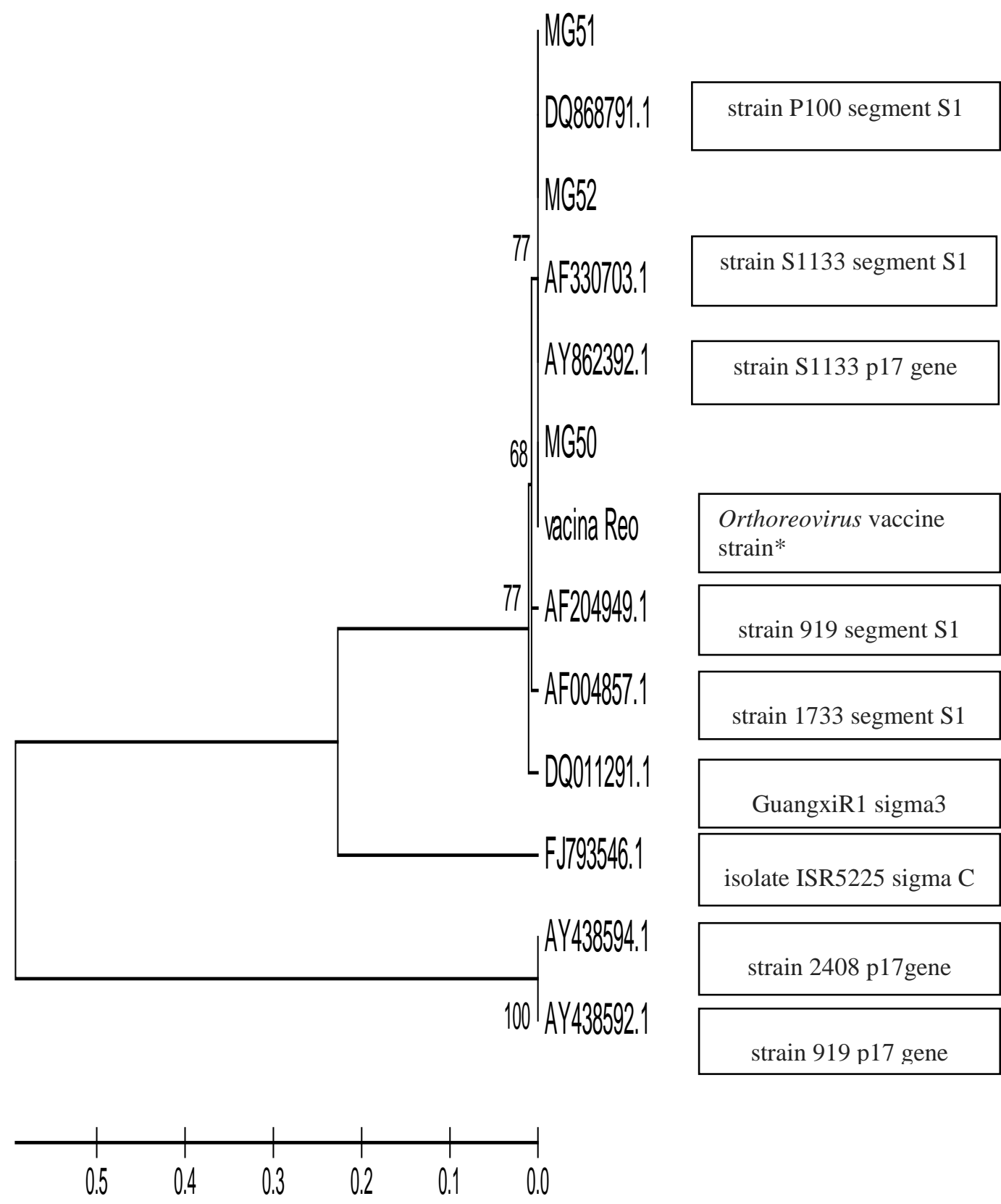

Figure 1. Phylogenetic tree of Orthoreovirus based on sequences of cell attachment protein $\sigma 1$ encoding gene. Isolates MG50, MG51 and MG52 were grouped with the S1133 strains of Europe, United States and strains employed as attenuated vaccines in Brazil. The scale bar indicates nucleotide substitutions per site. GenBank accession numbers are employed for each reference sequence.

* PoulvacMaternavac IBD-Reo vaccine (Fort Dodge). 
AvRV was only detected in broilers, in agreement with previous studies (McNulty et al., 1983, Alfieri et al., 1989). Rotaviruses have been shown to be the most important etiologies associated to gastro-enteric pathology, including results in Brazil (Alfieri et al., 1988 and 1989; Alfieri et al., 1992; Tamehiro et al., 2003; Villareal et al., 2006). The occurrence in two broiler flocks of the same region could be associated to the concentration of flocks and lack of biosecurity. The preclinical incubation infection period might be the reason for its presence in a normal flock, although replicating the virus would last for less than 5 days (McNulty, 2003). Positive samples were found in broilers from 16 to 31 days of age, results which are in agreement with the literature, which reports the occurrence after the second week of age, possibly associated to the decline of passive immunity and increased ambient titers for challenge (McNulty et al. 1983).

Previous AvRV studies in Brazil have found an $8.5 \%$ occurrence (Tamehiro et al., (2003), results which are similar to those here described (9.25\%). The presence of AvRV in mostly clinically affected flocks might suggest an association of its detection with infection, clinical signs and retarded growth (Barnes, 1977; Villareal, 2006). A higher prevalence of $13.81 \%$ of avian rotavirus infection was found in chickens in Bangladesh (Karim et al., 2007). However, rotavirus-like electrophoretic mobility, distinct of groups A, D and F, was detected ( 0 to $2.43 \%$ ) in broilers in Bangladesh (Ahmed and Ahmed, 2006). Our investigation did not allow such comparison.

Other etiologies might have a significant role for the enteric impairment. It was interesting to know that, for one diarrheic flock, no ARV or AvRV were detected, suggesting other causes of diarrhea, the most commonly being errors in ration formulation, coccidiosis, mycotoxins, other toxins and possibly other viral etiologies, such as other enteric virus (Alfieri et al., 1988; McNulty, 2003; Reynolds and Schultz, 2003; Rosenberger, 2003; Tamehiro et al., 2003).

\section{CONCLUSIONS}

After 23 years of the initial description in Minas Gerais, this is an updating study, regarding the ARV and AvRV epidemiology in chickens in the state. ARV and AvRV have been detected in broilers of the poultry industry in three different intensive poultry mesoregions. However, no ARV or AvRV detection was achieved for pullets. Other etiologies for diarrhea might be present, as for one clinically affected flock, no ARV or AvRV were detected. The co-infection of ARV and CAV was detected in a flock severely affected by stunting and arthritis, suggesting synergism. Results reinforce the need for strict biosecurity of poultry in the state in order to reduce losses derived from these and other infections.

\section{ACKNOWLEDGEMENTS}

This work is part of the National Institute of Science and Technology (Instituto Nacional de Ciência e Tecnologia-INCT), Genetic and Health Information of the Brazilian Livestock (Informação Genético-Sanitária da Pecuária Brasileira). Authors are indebted to $\mathrm{CNPq}$, FAPEMIG and FEP-MVZ for financial support.

\section{REFERENCES}

AHMED, M.S.; AHMED, M.U. Detection of Avian Rotavirus-like Virus in Broiler Chickens in Bangladesh. Bangladesh J. Vet. Med., v.4, p.73-77, 2006.

ALFIERI, A.A. Contribuição ao estudo da rotavirose suína no Brasil: Prevalência, ensaio imunoenzimático e eletroferotipagem. 1989. 150p. Dissertação (Mestrado em Microbiologia). Instituto de Ciências Biológicas/UFMG, Minas Gerais.

ALFIERI, A.F. Rotavirus e outros virus de genoma RNA fita dupla segmentado em fezes de aves. 1992. 180f. Dissertação (mestrado em Microbiologia). Instituto de Ciências Biológicas/UFMG, Minas Gerais.

ALFIERI, A.F.; ALFIERI, A.A.; RESENDE, J.S. et al. A novel bisegmented double-stranded RNA virus in avian faeces. Arq. Bras. Med. Vet. Zootec., v.40, p.437-440, 1988.

ALFIERI, A.F.; ALFIERI, A.A.; RESENDE, M. et al. Detection and propagation os avian enteric Reovírus in chicken. Arq. Bras. Med. Vet. Zootec., v.41, p.493-501, 1989. 
ANDRAL, B.; TOQUIN, D.; L'HARIDON, R. et al. Les diarrhées du dindonneau: unbilan dês recherches virales effectuées (Rotavírus, Reovírus, Adenovírus, Pseudopicornavirus). Avian Pathol., v.14, p.147-162, 1985.

APPLE, R,O.; SKEELES, J.K.; HOUGHTEN, G.E. et al. Investigation of a chronic feedpassage problem in a broiler farm in a Northwest Arkansas. Avian Dis., v.35, p.422-425. 1991.

BARRIOS, P.R.; MARIN, S.Y.; RESENDE, M. et al .Occurrence of chicken anemia virus in backyard chickens of the metropolitan region of Belo Horizonte, Minas Gerais. Rev. Bras. Cienc. Avic., v.11, p.135-138, 2009.

BARNES, H.J. Viral enteric infection In: CALNEK, B.W.; BAENES, H.J.; BEARD, C.W. et al. Diseases of Poultry. Iowa: Iowa state university press. 1977. p.685-686.

BURGOS, S.; EDENS, F.; READ-SNYDER, F. et al. Selenium Sources Affect Protein Concentration, Thioredoxin Reductase Activity and Selected Production Parameters in Reovirus Infected Broiler Chickens. Int. J. Poult. Sci., v.5, p.822-829, 2006.

CARDONA, C.J., OSWALD, W.B., SCHAT, K.A. Distribution of chicken anemia virus in the reproductive tissues of specific pathogen free chickens. J. General Virol., v.81, p.2067-2075, 2000.

CHEN, Z.; ZHU, Y.; LI, C.; LIU, G. Outbreakassociated novel duck reovirus, China, 2011.Emerging Infectious Diseases. 2012. Disponível em: http://dx.doi.org/10.3201 /eid1807.120190. Acessado em 09/07/2012.

DECAESSTECKER， M.; CHARLIER， G.; MEULEMANS, G. Epidemiological study of enteric viruses in broiler chickens: Comparasion of Tissue culture and direct electron microscopy. Avian Pathology, v.17, p.477-486, 1988.

FLEWETT, T.; WOOD, G.N. The rotaviruses: brief review. Arch. Virol., v.57, p.1-23, 1978.

GOMES, A.D.; ABREU, J.T.; REDONDO, R.A.F. et al. Genotyping of IBDV strains by restriction fragment length polymorphism of the VP1, VP2 and VP3 genes. Avian Dis., v.49, p.500-506, 2005.
GOUCH, R.E.; ALEXANDER, D.J.; COLLINS, M.S. et al. Routine virus isolation for detection for detection in the diagnosis of diseases in birds. Avian Pathology., v. 17, p. 893-907, 1988

HALL, T.A. BioEdit: A user-friendly biological sequence alignment editor and analysis program for Windows 95/98/NT. Nucleic Acids Symp. Series, v.41, p.95-98, 1999.

HERRING, A.J.; INGLIS,N.F.; OJEH, C.K. et al. Rapid Diagnosis of Rotavirus Infection by Direct Detection of Viral Nucleic Acid in SilverStained Polyacrylamide Gels. J. Clin. Microbiol., v.16, p.473-477, 1982.

JONES, R.C.; JORDAN, F.T.W.; LIOUPIS. S. Characteristics of reovirus isolated from ruptured gastrocnemius tendons of chickens. Vet. Record, v.96, p.153-154. 1975.

JONES, R.C.; GEORGIOU, K. Reovirusinduced tenosynovitis in chickens: The influence of age at infection. Avian Pathol., v.13, p.441457, 1984.

KARIM, M.R.; RUMEL, F.I.; ALAM, M.M. et al. Molecular epidemiologic study on avian rotavirus prevailing in Bangladesh. Bangladesh J. Vet. Med., v.5, p.43-48, 2007.

LENZ, S.D.; HOERR, F.J.; ELLIS, A.C.et al. Gastrointestinal pathogenicity of Adenoviruses and reoviruses isolated from broiler chickens in Alabama. Avian Diseases, v.10, p 145-151, 1998.

LIU, J.H.; GIAMBRONE, J.J.; NIELSEN, B.L. Molecular characterization of avian reoviruses using nested PCR and nucleotide sequence analysis. J. Virological Methods, v.65, p.159167, 1997.

MARTINS, N.R.S.; RESENDE, J.S. Adenoviroses, reoviroses, rotaviroses e viroses intestinais. In. BERCHIERI Jr., A.; SILVA, E.N.; DI FABIO, J. Doenças das aves. Campinas: Fundação APINCO de Ciência e Tecnologia Avícola, cap. 5.6 p.677-710, 2009.

McNEILLY, F.; SMYTH, J.A.; ADAIR, B.M. et al. Synergism between Chicken Anemia Virus (CAV) and Avian Reovirus Following Dual Infection of 1-Day-Old Chicks by a Natural Route. Avian Diseases, v.39, p.532-537, 1995. 
McNULTY, M.S.; ALLAN, G.M., TODD, D.; McFERRAN, J,B. Isolation and cell culture propagation of rotaviruses from turkeys and chickens. Archieves of Virology. v.61 , p.13, 1979.

McNULTY, M.S. Rotavirus Infections. Diseases of Poultry, Saif et al. Editors, 11th ed., Iowa State Press: Blackwell Publishing Company, Ames, Iowa, p.308-320, 2003.

McNULTY, M.S.; ALLAN, G.M.; TODD, D. et al. Isolation of rotaviruses from turkeys and chickens: demonstrations of distinct serotypes and RNA eletropherotypes. Avian Pathol., v.9, p.363-375, 1980 .

McNULTY, M.S.; ALLAN, G.M.; McCRACKEN, R.M., Experimental infection of chickens with rotaviruses: clinical and virological findings. Avian Pathol., v.12, p.45$54,1983$.

McFERRAN, J.B.; McNULTY, M.S.; McCRACKEN, P.M. et al. Enteritis and associated problems. In: HUNGERFORD, T.G. Disease Prevention and Control in Poultry Production. Sidney: University Press, 1983. p.129-138.

REYNOLDS, D.L.; SCHULTZ-CHERRY, S.L. Astrovirus. In: Saif et al. Diseases of Poultry. $11^{\text {th }}$ ed. Iowa State Press:Blackwell Publishing Company. 2003. p.320-325.

RIOS, R.L.; MARIN, S.Y.; GOMES, A.D. et al. Ocorrência de Reovírus em Regiões da Avicultura Industrial de Minas Gerais. Anais do Simpósio APINCO, Prêmio Lamas, Sanidade, SA031, 2010.

ROSENBERGER J.K. Reovirus Infections. Diseases of Poultry, Saif et al. Editors, 11th ed. Iowa State Press: Blackwell Publishing Company, Ames, Iowa, 2003. p.283-298.
RUFF, M.D.; ROSENBERGER, J.K. Concurrent infections with reoviruses and coccidian in broilers. Avian Diseases, v.29, p.465-478, 1985.

SANGER, F.; NICKLEN, S.; COULSON, A.R. DNA sequencing with chain-terminating inhibitors. Proceedings of National Academy of Science of USA 74: 5463-5467, 1997.

SCHIFF, L.A.; NIBERT, M.L.; TYLER, K.L. Orthoreoviruses and Their Replication. In: Fields Virology, 5th Edition, Lippincott Williams \& Wilkins, p. 1853-1915, 2007.

SONGSERM, T.; ROOZELAAR, D.; KANT, A. et al. Enteropathogenicity of Dutch and German avian reoviruses in SPF white leghorn chickens and broilers. Vet. Res., v.34, p.285-295, 2003.

TAMEHIRO, C.Y.; ALFIERI, A.F.; MÉDICI, K.C. et al. Segmented double-stranded genomic RNA viruses in fecal samples from broiler chicken. Braz. J. Microbiol., v.34, p.349-353, 2003.

VAN DER HEIDE, L.; KALBAC, M., Infectious tenosynovitis (viral arthritis): characterization of a Connecticut viral isolant as a reovirus and evidence of viral egg transmission by reovirusinfected broiler breeders, Avian Dis., v.19, p.683688, 1975.

VILLAREAL, L.Y.B. Detecção de um coronavírus entérico em aves de corte, poedeiras comerciais e matrizes:Distribuição, diversidade molecular e diagnóstico diferencial com outros vírus entéricos aviários. 2006. 96f. Tese (Doutorado em Patologia experimental e comparada. Faculdade de Medicina Veterinária e Zootecnia/USP), São Paulo. 